\title{
Variation among Strawberry Cultivars in Bruising Susceptibility Related to Wound Ethylene Production and Sensitivity
}

\author{
Lan-Yen Chang and Jeffrey K. Brecht \\ Horticultural Sciences Department, University of Florida/IFAS, Gainesville, \\ FL 32611
}

Additional index words. calyx yellowing, decay, Fragaria $\times$ ananassa, mechanical injury, respiration, water soaking

\begin{abstract}
Bruising of strawberry (Fragaria Xananassa Duch.) fruit is a common mechanical injury that reduces product value. Wound-induced ethylene may accelerate deterioration or decay, affecting strawberry quality and shelf life. However, bruising susceptibility varies among strawberry cultivars. In this study, cultivars Monterey, Sweet Sensation, Radiance, and two proprietary cultivars (Cultivar A and Cultivar B) from a private breeding program were investigated to evaluate their bruising susceptibility and wound response. Bruising consisted of dropping a 28-g steel ball from $27 \mathrm{~cm}$ onto individual fruit; unbruised fruit were the primary control, while fruit exposed to 1 $\mu L \cdot L^{-1}$ ethylene were used as a check for ethylene response. All fruit were stored at $20{ }^{\circ} \mathrm{C}, 90 \%$ relative humidity $(\mathrm{RH})$, with respiration and ethylene production measured at 2-hour intervals for 24 hours. Appearance observations were recorded daily until decay onset. Peak respiration rates of 30-40 $\mathrm{mL} \mathrm{CO} \cdot \mathrm{kg}^{-1} \cdot \mathrm{h}^{-1} \operatorname{mostly}$ occurred within 4 hours ('Cultivar B') to 6 hours ('Cultivar A' and 'Sweet Sensation') after bruising, except 'Monterey', which peaked at $60 \mathrm{~mL} \mathrm{CO} \cdot \mathrm{kg}^{-1} \cdot \mathrm{h}^{-1}$ in 2 hours, and 'Radiance', which reached $70 \mathrm{~mL} \mathrm{CO} \cdot \mathrm{kg}^{-1} \cdot \mathrm{h}^{-1}$ in 6 hours. Maximum ethylene production rates after bruising were 0.05 to $0.06 \mu \mathrm{L} \cdot \mathrm{kg}^{-1} \cdot \mathrm{h}^{-1}$ for 'Monterey', 'Cultivar A', and 'Cultivar B', $0.10 \mu \mathrm{L} \cdot \mathrm{kg}^{-1} \cdot \mathrm{h}^{-1}$ for 'Sweet Sensation', and 0.20 to $0.37 \mu \mathrm{L} \cdot \mathrm{kg}^{-1} \cdot \mathrm{h}^{-1}$ for 'Radiance'. 'Cultivar B', with the lowest ethylene production, exhibited the lowest overall bruising severity, whereas 'Radiance', with the highest ethylene production, exhibited the most severe bruising-induced water soaking, and the other cultivars were intermediate, although 'Monterey' bruises were more discolored than those of the other cultivars. 'Monterey', 'Radiance', and 'Sweet Sensation' showed more yellowing and browning of the calyx in response to both bruising and ethylene exposure than ' $C u l t i v a r ~ A$ ' and 'Cultivar B'. Except for 'Cultivar B', bruising and ethylene exposure increased decay severity.
\end{abstract}

Strawberry (Fragaria ×ananassa Duch.), the third most consumed fresh fruit in the U.S. market in 2017 (USDA, 2019), is attractive and highly valued, but it is delicate. Large cells with thin cell walls result in the fragile structure of strawberry fruit (Szczesniak and Smith, 1969), which become more susceptible to mechanical injury as the ripening process proceeds. Strawberries are harvested when mostly or fully ripe according to the commercial standard for U.S. No. 1 grade, which states that strawberry fruit must be at least $3 / 4$ red (USDA, 2006). Bruising occurs mainly during harvesting, packing, and transportation for hor-

Received for publication 15 Nov. 2019. Accepted for publication 3 Jan. 2020.

Published online 25 February 2020.

We thank It's Fresh Ltd. for their support by providing research funding for this work.

J.K.B. is the corresponding author. E-mail: jkbrecht@ ufl.edu.

This is an open access article distributed under the CC BY-NC-ND license (https://creativecommons. org/licenses/by-nc-nd/4.0/). climacteric fruits such as banana and tomato to produce an increasing amount of ethylene (Moretti et al., 1998; Palmer and McGlasson, 1969). However, strawberry fruit is often regarded as a nonclimacteric and ethyleneinsensitive crop. In previous research, some researchers have suggested that ethylene could not only stimulate the respiration rate of nonclimacteric fruit, but also accelerate fruit color development, softening, and ion leakage, with a deleterious logarithmic linear response to 10 to $<0.005 \mu \mathrm{L} \cdot \mathrm{L}^{-1}$ ethylene in terms of shelf life (Wills and Kim, 1995; Wills and Wong, 1996; Wills et al., 1999). In contrast, other researchers have presented evidence showing little or no effect of ethylene on strawberries (El-Kazzaz et al., 1983; Tian et al., 2000). The role of ethylene in nonclimacteric fruit wounding response is uncertain, and the differential response toward ethylene in previous studies was reported to be affected by maturity, storage time, and cultivar characteristics (El-Kazzaz et al., 1983; Picón et al., 1993; Tian et al., 2000).

In tests to determine the potential benefits of removing ethylene from the strawberry postharvest environment that were conducted before the present research (Brecht et al., 2016), we observed significant cultivar variation in response to ethylene scrubbing in terms of bruising severity and calyx yellowing and browning. We hypothesized that those differences in response to ethylene scrubbing might be related to differences in wound ethylene production or ethylene sensitivity among the cultivars that had been tested. Therefore, in this study, several major commercial strawberry cultivars, including Monterey, Sweet Sensation (Florida 127), Florida Radiance, and two proprietary cultivars (Cultivar A and Cultivar B) from a private breeding program, were investigated to determine their bruising susceptibility and wound response in terms of timing and the rate of wound ethylene production to inform further improvements in postharvest procedures.

\section{Materials and Methods} accelerated senescence, thus affecting strawberry quality and shelf life (Ferreira et al., 2009; Wills and Kim, 1995). The severity of wounding in strawberry depends on various factors, including the type of force applied on the fruit, cooling method, and rate of lowering pulp temperatures, along with the storage temperature (Ferreira et al., 2009). Internal fruit properties, such as texture, fruit maturity, water content, firmness, size, and shape (Hung and Prussia, 1989; Van Linden et al., 2006), and the nature of cultivars (Jiménez-Jiménez et al., 2013; Kunze et al., 1975) also contribute to the bruising response. Bruising severity and the tissues being affected can be determined by dissecting the fruit and measuring the bruise diameter, depth, and volume, which have strong positive correlations with impact energy (Schoorl and Holt, 1980).

Mechanical injury, such as cutting, abrasion, or bruising, has been shown to cause
Plant material. Strawberry fruit of the University of California licensed cultivar Monterey (received 24 Oct. 2017), two cultivars licensed by the University of Florida, namely Sweet Sensation (Florida 127) (Sweet Sensation) (received 11 Dec. 2017) and Florida Radiance (Radiance) (received 21 Mar. 2018), and two proprietary cultivars, Cultivar A (4 Oct. 2017) and Cultivar B (11 Dec. 2017), were received from distribution centers of retailers at the beginning of the harvest season for each variety and immediately transported to the University of Florida Postharvest Horticulture Laboratory in Gainesville by airconditioned van at $\approx 18{ }^{\circ} \mathrm{C}$ within $2 \mathrm{~h}$. Five separate experiments were conducted. Additional experiments conducted with 'Radiance' (once) and 'Sweet Sensation' (twice) showed similar results and are not presented here. On arrival at the laboratory, fruit were stored at 

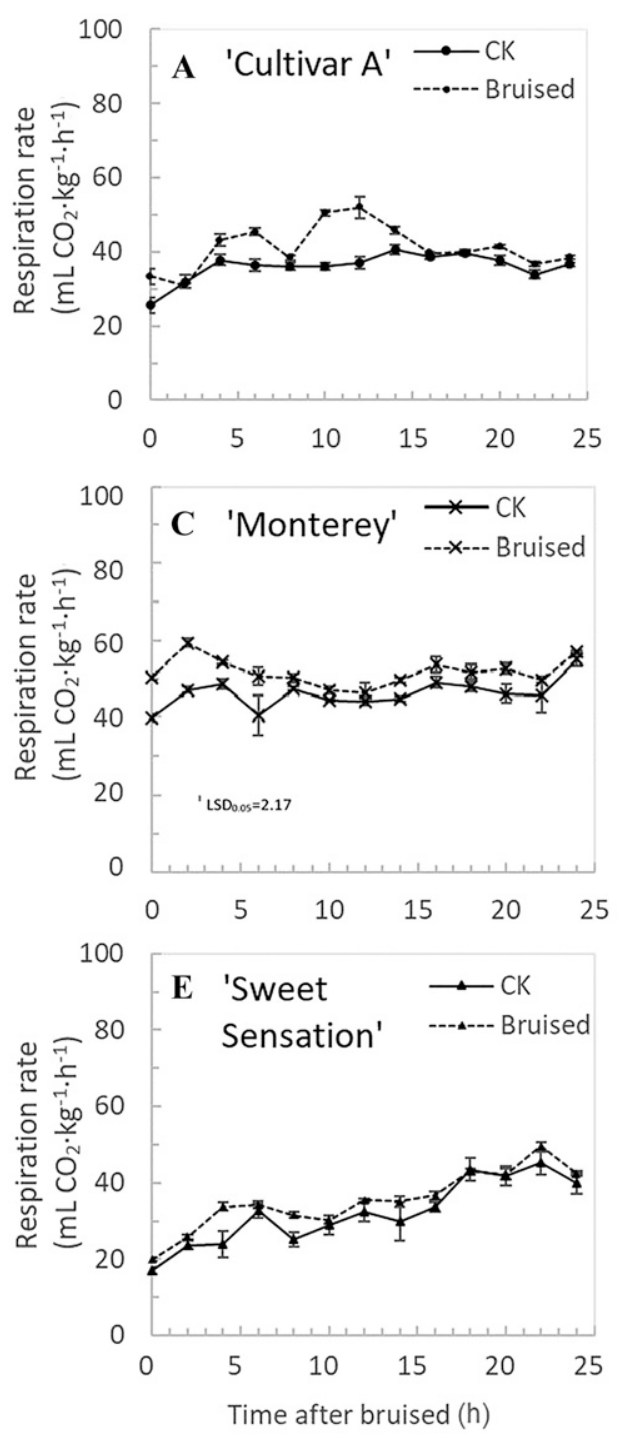

Fig. 1. Time course within $24 \mathrm{~h}$ for the respiration rate of (A) 'Cultivar A', (B) 'Cultivar B', (C) 'Monterey', (D) 'Radiance', and (E) 'Sweet Sensation' fruit with control (CK, solid line) and bruised (Bruised, dash line) fruit during storage at $20^{\circ} \mathrm{C}$ and $95 \%$ relative humidity. Each data point represents the mean of three observations. Vertical bars represent SE.

$1{ }^{\circ} \mathrm{C}$ overnight to reduce the disturbance of the physiological response during transportation. Fruit were rewarmed to ambient temperature $\left(24^{\circ} \mathrm{C}\right)$ the following day and fully red fruit, selected for uniform color, size, and freedom from defects, were grouped into three replicate groups of similar weight per cultivar $(900 \mathrm{~g}$ for 'Cultivar A', $800 \mathrm{~g}$ for 'Monterey', and 650 to $670 \mathrm{~g}$ for 'Sweet Sensation', 'Radiance', and 'Cultivar B').

Treatments. To examine whether the wound response in strawberry fruit involves ethylene, bruised fruit (BR), fruit treated with $1 \mu \mathrm{L} \cdot \mathrm{L}^{-1}$ ethylene $(\mathrm{ETH})$, and untreated fruit as control (CK) were used in the experiments. Bruising treatment followed the procedure of Ferreira et al. (2008) with modifications to deliver the same impact energy to the fruit. A 28 -g steel ball was released from a height of $26.67 \mathrm{~cm}$ within a plastic tube directed to the proper impact point on individual fruit at $24{ }^{\circ} \mathrm{C}$ on the fullest part of the side of the fruit; the applied impact energy was $\approx 0.74 \mathrm{~J}$.
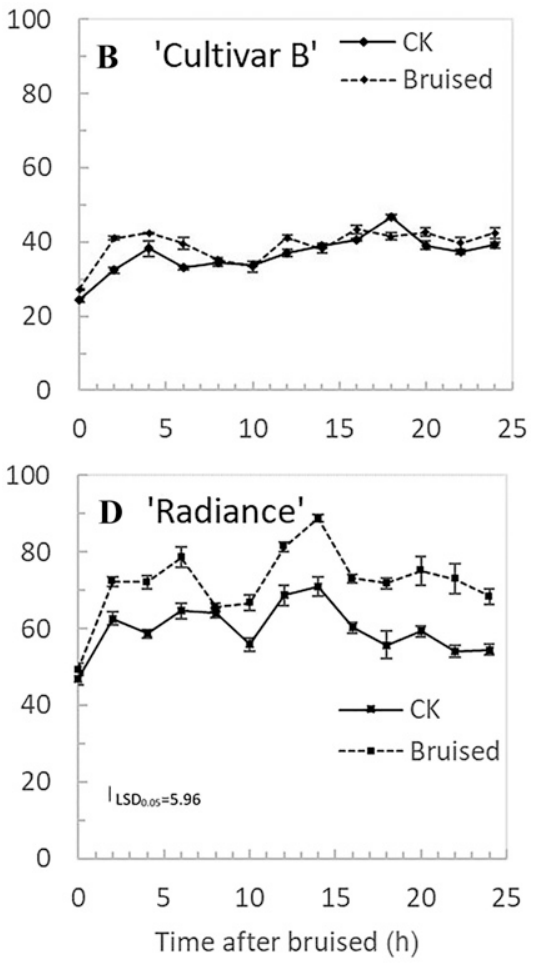
$149-177$ ( $\mathrm{m} \times 3.18 \mathrm{~mm})$ [particle size, 149-177 $\mu \mathrm{m}(80 / 100 \mathrm{mesh})]$ and Molsieve $13(1.5 \mathrm{~m} \times 3.18 \mathrm{~mm})$ [particle size, 149$177 \mu \mathrm{m}(80 / 100 \mathrm{mesh})]$ columns (Varian) coupled in series to the TCD. The carrier gas (helium) flow rate was $0.25 \mathrm{~mL} \cdot \mathrm{s}^{-1}$. The injector and oven were operated at $220{ }^{\circ} \mathrm{C}$ and $50{ }^{\circ} \mathrm{C}$, respectively. The PDHID was operated at $120^{\circ} \mathrm{C}$ and the TCD was operated at $130^{\circ} \mathrm{C}$.

Assessment of wound response. At $24 \mathrm{~h}$ after treatment, the bruise diameters of each fruit were measured from edge to edge on two perpendicular axes with a caliper and averaged. Defects of BR, CK, and ETH strawberry fruit, including the bruised area on BR fruit, water soaking or darker color of bruised areas, calyx degreening, and decay were photographed and evaluated for each fruit at $24 \mathrm{~h}$ after treatment and daily until the onset of decay using the incidence rates of the defects. Evaluations of bruising symptoms for CK and ETH treatments were performed for incidentally bruised areas that were not evident during initial sorting because those fruit had not been intentionally bruised like the BR fruit.

Statistical analysis. Carbon dioxide and ethylene production rate data over time were analyzed by a one-way repeated measure analysis of variance (ANOVA) of each cultivar, and bruise diameters among cultivars were analyzed by one-way ANOVA with the JMP Pro 14.1.0 (SAS Institute, 2019) software and Microsoft Excel (version 1910; Microsoft Office 365; Microsoft, Redmond, WA). Fisher's least significant differences $(P \leq 0.05)$ were determined to compare differences between treatment means following a significant ANOVA effect. Mean data are presented ( $($ SEM).

\section{Results and Discussion}

Respiration and ethylene production during the first $24 \mathrm{~h}$ after treatment among different cultivars. Bruising treatment stimulated respiration of all cultivars. Respiration rates for each cultivar differed (Fig. 1), with 'Radiance' having the highest rate, followed by 'Monterey', 'Cultivar A', and 'Cultivar B'; 'Sweet Sensation' had the lowest rate. Peak respiration rates of 34.14 and $45.38 \mathrm{~mL}$ $\mathrm{CO}_{2} \cdot \mathrm{kg}^{-1} \cdot \mathrm{h}^{-1}$ occurred at $6 \mathrm{~h}$ after bruising for 'Sweet Sensation' and 'Cultivar A', respectively, and $42.47 \mathrm{~mL} \mathrm{CO} \mathrm{CO}^{-1} \cdot \mathrm{h}^{-1}$ occurred at $4 \mathrm{~h}$ after bruising for 'Cultivar B'. Peak respiration rates after bruising for 'Monterey' 


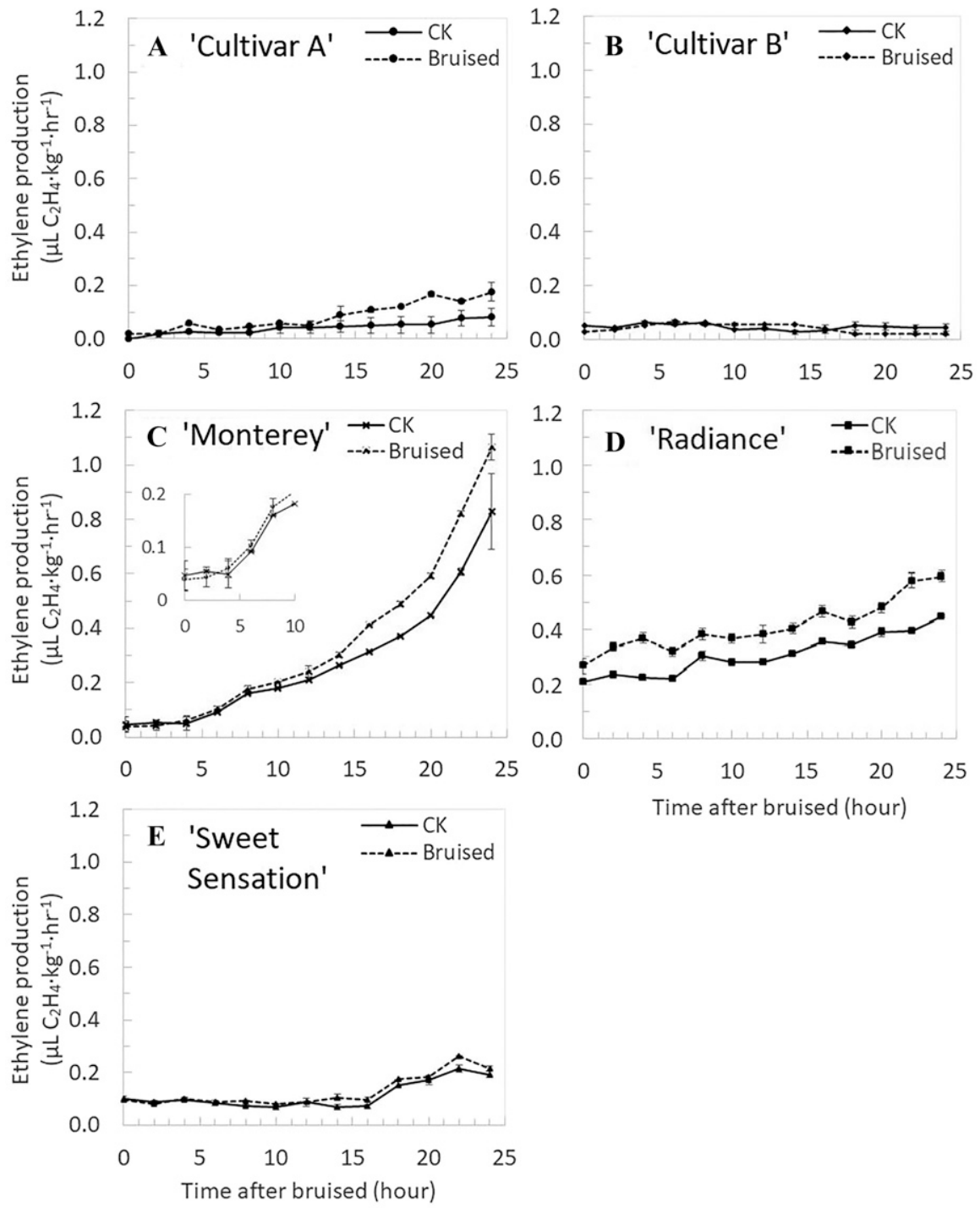

Fig. 2. Time course within $24 \mathrm{~h}$ for the ethylene production rate of (A) 'Cultivar A', (B) 'Cultivar B', (C) 'Monterey', (D) 'Radiance', and (E) 'Sweet Sensation' fruit with control (CK, solid line) and bruised (Bruised, dash line) fruit during storage at $20^{\circ} \mathrm{C}$ and $95 \%$ relative humidity. Each data point represents the mean of three observations. Vertical bars represent SE.

Table 1. Bruise diameters of 'Cultivar A', 'Cultivar B', 'Monterey', 'Radiance', and 'Sweet Sensation' stored at $20{ }^{\circ} \mathrm{C}$ and $95 \%$ relative humidity measured $24 \mathrm{~h}$ after bruising.

\begin{tabular}{lc}
\hline Cultivar & Bruise diam $(\mathrm{mm})$ \\
\hline Cultivar A & $12.34 \pm 0.55 \mathrm{a}^{\mathrm{z}}$ \\
Cultivar B & $8.98 \pm 0.22 \mathrm{c}$ \\
Monterey & $10.55 \pm 0.39 \mathrm{~b}$ \\
Radiance & $9.10 \pm 0.20 \mathrm{c}$ \\
Sweet Sensation & $9.03 \pm 0.26 \mathrm{c}$ \\
LSD $_{0.05}$ & 1.34
\end{tabular}

${ }^{2}$ Means followed by the same letter in the column are not significantly different according to the least significant difference (LSD) test $(P>0.05) . \mathrm{n}=15$ fruits.

$\left(59.58 \mathrm{~mL} \mathrm{CO} \cdot \mathrm{kg}^{-1} \cdot \mathrm{h}^{-1}\right.$ in $\left.2 \mathrm{~h}\right)$ and 'Radiance' $\left(78.63 \mathrm{~mL} \mathrm{CO} \cdot \mathrm{kg}^{-1} \cdot \mathrm{h}^{-1}\right.$ in $6 \mathrm{~h}$ ) were higher than those for the other cultivars. Respiration rates of 'Radiance' and 'Monterey' were also significantly higher than those for the other cultivars over the entire $24 \mathrm{~h}$ after treatment.
The ethylene production after $12 \mathrm{~h}$ for 'Cultivar A', 'Monterey', 'Sweet Sensation', and 'Radiance' increased up to 2- to 10-fold, presumably due to the development of decay caused by gray mold (Botrytis cinerea). Infection of $B$. cinerea has been reported to accelerate the ethylene production by the affected host plant tissues and by the fungus itself, with ethylene promoting decay of nearby tissues or fruit (Chague et al., 2002; Qadir et al., 1997).

Tian et al. (2000) indicated that enhanced respiratory rate in response to exogenous ethylene exposure depended on the ethylene concentration and the treatment duration, with fruit treated with $1 \mu \mathrm{L} \cdot \mathrm{L}^{-1}$ ethylene for $2 \mathrm{~d}$ observed to produce more $\mathrm{CO}_{2}$. Even though ethylene production rates for 'Radiance' and 'Monterey' in the present work were comparatively higher than those for the other cultivars, it did not appear to affect the respiration rate. However, ethylene and $\mathrm{CO}_{2}$ production rates of 'Sweet Sensation' increased synchronously after $16 \mathrm{~h}$ (Figs. 1C and 2C), which might have been due to greater sensitivity to ethylene in that cultivar.

Comparison of appearances among different treatments within each cultivar. Bruise diameters measured at $24 \mathrm{~h}$ after bruising were significantly larger for 'Cultivar A' and 'Monterey' compared with 'Cultivar B', 'Radiance', and 'Sweet Sensation', which were not significantly different from each other (Table 1).

Defects among cultivars and treatments were categorized into four major symptoms, including decay, calyx yellowing or browning, fruit with water soaking, and fruit with darker damaged areas (Table 2). Decay was mostly represented by Botrytis fruit rot (gray mold), which manifested the symptoms of light brown spots or gray fuzzy coating on the fruit surface. Decay developed more rapidly in 'Cultivar A', 'Monterey', and 'Radiance' than in 'Cultivar B' and 'Sweet Sensation'. Fruit of 'Cultivar B' had the least amount of fruit infected by the fungus, whereas 'Monterey' and 'Radiance' were more susceptible.

The growth of $B$. cinerea was reported to be accelerated by $20 \mu \mathrm{L} \cdot \mathrm{L}^{-1}$ ethylene (ElKazzaz et al., 1983). 'Radiance' produced the most ethylene among the cultivars, and the BR fruit maintained ethylene production at higher rates than the $\mathrm{CK}$ fruit. After the initial wound ethylene production following bruising, an additional increase in ethylene production started after $12 \mathrm{~h}$, which was associated with accelerated fungal growth. Initial ethylene production of 'Monterey' was relatively low, at $\approx 0.03 \mu \mathrm{L} \cdot \mathrm{kg}^{-1} \cdot \mathrm{h}^{-1}$, but the production increased starting from the sixth hour, with $\mathrm{BK}$ fruit producing more ethylene than CK fruit, which may have been related to enhanced growth of the fungus. However, neither bruising treatment nor ethylene exposure consistently promoted decay in the strawberry cultivars tested (Table 2). 'Cultivar B', which did not exhibit increased ethylene production in response to bruising, also did not exhibit increased decay in either the BR or the ETH treatments, whereas 'Sweet Sensation' showed increased decay 


\begin{tabular}{|c|c|c|c|c|c|}
\hline \multirow[b]{2}{*}{ Cultivar } & \multirow[b]{2}{*}{$\begin{array}{c}\text { Days before decay } \\
\text { onset }\end{array}$} & \multicolumn{4}{|c|}{ Major defects ${ }^{z}$} \\
\hline & & Decay & $\begin{array}{c}\text { Calyx } \\
\text { yellowing/browning }\end{array}$ & $\begin{array}{l}\text { Fruit water } \\
\text { soaking }\end{array}$ & $\begin{array}{c}\text { Fruit with darker } \\
\text { damage area }\end{array}$ \\
\hline \multicolumn{6}{|l|}{$\overline{\text { Cultivar A }}$} \\
\hline Control & 2 & 1 & 2 & 2 & 1 \\
\hline Bruised $(0.74 \mathrm{~J})$ & & 3 & 3 & 3 & 2 \\
\hline Ethylene (1 ppm) & & 3 & 3 & 2 & 2 \\
\hline \multicolumn{6}{|l|}{ Cultivar B } \\
\hline Control & 3 & 2 & 2 & 1 & 1 \\
\hline Bruised $(0.74 \mathrm{~J})$ & & 2 & 2 & 2 & 1 \\
\hline Ethylene (1 ppm) & & 2 & 3 & 2 & 1 \\
\hline \multicolumn{6}{|l|}{ Monterey } \\
\hline Control & 2 & 3 & 2 & 1 & 2 \\
\hline Bruised $(0.74 \mathrm{~J})$ & & 4 & 4 & 2 & 3 \\
\hline Ethylene (1 ppm) & & 4 & 4 & 2 & 3 \\
\hline \multicolumn{6}{|l|}{ Radiance } \\
\hline Control & 2 & 3 & 2 & 2 & 2 \\
\hline Bruised $(0.74 \mathrm{~J})$ & & 4 & 4 & 4 & 1 \\
\hline Ethylene (1 ppm) & & 4 & 4 & 2 & 1 \\
\hline \multicolumn{6}{|l|}{ Sweet Sensation } \\
\hline Control & 3 & 2 & 4 & 0 & 1 \\
\hline Bruised $(0.74 \mathrm{~J})$ & & 4 & 5 & 1 & 1 \\
\hline Ethylene (1 ppm) & & 2 & 5 & 0 & 2 \\
\hline Least significant difference at $P=0.05$ & & 0.71 & 0.64 & 1.29 & 0.50 \\
\hline Cultivar & & $* * * *$ & $* * * *$ & $* * * *$ & $* * * *$ \\
\hline Treatment & & $* * * *$ & $* * * *$ & $*$ & $* *$ \\
\hline Cultivar $\times$ treatment & & $* *$ & NS & NS & $* * * *$ \\
\hline
\end{tabular}

${ }^{\mathrm{z}}$ The proportion of total fruit presenting symptoms: $1: 0 \%$ to $20 \% ; 2: 21 \%$ to $40 \% ; 3: 41 \%$ to $60 \% ; 4: 61 \%$ to $80 \% ; 5: 81 \%$ to $100 \%$. $n=3$.

NS, *,**,***,****Nonsignificant or significant at $P=0.05,0.01,0.001$, or 0.0001 , respectively, according to the F-test.

in response to bruising, but not to ethylene exposure. These results indicate that for some strawberry cultivars, the amount of ethylene required to accelerate the growth of $B$. cinerea might be lower than the $20 \mu \mathrm{L} \cdot \mathrm{L}^{-1}$ ethylene reported previously by El-Kazzaz et al. (1983), but ethylene may have a small or no role in the development of Botrytis rot in other cultivars. However, the reduced levels of both wound ethylene production and decay observed in 'Cultivar B' suggest that the selection of strawberry germplasm with reduced wound ethylene production may represent an avenue for developing strawberry cultivars with reduced postharvest decay.

'Monterey' fruit had the most yellowing and browning of the calyx in the BR and ETH treatments, followed by 'Radiance' and 'Sweet Sensation' (Table 2). Cultivar A and Cultivar B exhibited less calyx yellowing and browning than the other cultivars. The occurrence of calyx yellowing or browning probably resulted from the breakdown of chlorophyll in response to ethylene, which was also observed by Bower et al. (2003), followed by leaf senescence.

The bruised area was evaluated in terms of two different defects: water soaking, in which damaged tissues were moist and translucent, and dry damaged area, in which there was dry and shrunken tissue. 'Radiance', followed by 'Cultivar A', had relatively more bruised fruit that developed water soaking, whereas 'Monterey' had more fruit with darker damaged areas than other cultivars.

Major defects observed in each cultivar in response to bruising were different. Decay, calyx yellowing/browning, and fruit with darker damaged areas were the major symp- toms observed in 'Monterey'. For 'Radiance', decay, calyx yellowing/browning, and fruit with water soaking were the major symptoms, while 'Cultivar A' had more fruit with water soaking. Among all tested cultivars, Cultivar B exhibited the lowest bruising severity, whereas 'Monterey', 'Radiance', and 'Cultivar A' were more susceptible to bruising but responded with different symptoms. Saltveit (1997) described the first physical effects of wounding, which include removal of the protective epidermal layer, deposition of surface moisture (from the contents of broken cells), and exposure of the inner tissues to contaminants, including decay organisms. Water evaporation from the wound surface occurs later and the plant starts to respond physiologically to the wound. Surface water is first deposited and then lost as activation of healing proceeds. In this trial, most bruised fruit of 'Cultivar A' and 'Radiance' exhibited surface water in the damaged area where decay usually started. Other cultivars had more fruit with darker damaged areas where decay randomly spread. The healing processes activated after wounding among these cultivars were different and were presumably affected by the earlier wound response.

It would seem plausible that relative differences in wound ethylene production among strawberry cultivars may be, at least partly, a result of differences in the amount of damaged tissue resulting from the application of the same force. However, our results indicated that the cultivars with larger bruises (i.e., 'Cultivar A' and 'Monterey') had lower rates of wound ethylene production, suggesting that there are inherent genetic differences among these cultivars regarding wound ethylene production capacity.
In conclusion, bruising susceptibility varied among strawberry cultivars in terms of their responses, namely, respiration rate, ethylene production, and the phenotypic wound defects after being bruised. 'Monterey', 'Radiance', and 'Cultivar A' were more susceptible to bruising than 'Sweet Sensation' and 'Cultivar B', and they showed more ethyleneenhanced symptoms, including darker color or more severe water soaking at the injured area, or yellowing/browning of the calyx compared with unbruised CK fruit. 'Cultivar B', with the lowest ethylene production, also exhibited the lowest bruising severity, calyx yellowing/browning, and decay, whereas 'Radiance', with the highest ethylene production, exhibited the most severe bruise water soaking and among the most severe calyx yellowing/browning and decay.

\section{Literature Cited}

Bower, J.H., W.V. Biasi, and E.J. Mitcham. 2003. Effect of ethylene and 1-MCP on the quality and storage life of strawberries. Postharvest Biol. Technol. 28:417-423.

Brecht, J.K., S.A. Sargent, D.J. Huber, and R. Suthar. 2016. Efficacy of It's Fresh! palladium ethylene scrubber in reducing ethylene and extending strawberry quality. ISHS VIII Intl. Strawberry Symp., Quebec City, Quebec, Canada, 16 Aug. (abstr.).

Chague, V., Y. Elad, R. Barakat, P. Tudzynski, and A. Sharon. 2002. Ethylene biosynthesis in Botrytis cinerea. FEMS Microbiol. Ecol. 40:143149 .

El-Kazzaz, M.K., N.F. Sommer, and R.J. Fortlage. 1983. Effect of different atmospheres on postharvest decay and quality of fresh strawberries. Phytopathology 73:282-285.

Ferreira, M.D., S.A. Sargent, J.K. Brecht, and C.K. Chandler. 2008. Strawberry fruit resistance to simulated handling. Sci. Agr. (Piracicaba, Braz.) 65:490-495. 
Ferreira, M.D., S.A. Sargent, J.K. Brecht, and C.K. Chandler. 2009. Strawberry bruising sensitivity depends on the type of force applied, cooling method, and pulp temperature. HortScience 44:1953-1956.

Hung, Y.C. and S.E. Prussia. 1989. Effect of maturity and storage time on the bruise susceptibility of peaches (cv. 'Red Globe'). Trans. ASAE 32:1377-1382.

Jiménez-Jiménez, F., S. Castro-García, and J.A. Gil-Ribes. 2013. Table olive cultivar susceptibility to impact bruising. Postharvest Biol. Technol. 86:100-106.

Kunze, D.R., W.H. Aldred, and E.D. Reeder. 1975. Bruising characteristics of peaches related to mechanical harvesting. Trans. ASAE 18:939-945.

Moretti, C.L., S.A. Sargent, D.J. Huber, A.G. Calbo, and R. Puschmann. 1998. Chemical composition and physical properties of pericarp, locule and placental tissues of tomatoes with internal bruising. J. Amer. Soc. Hort. Sci. 123:656-660.

Palmer, J.K. and W.B. McGlasson. 1969. Respiration and ripening of banana fruit slices. Austral. J. Biol. Sci. 22:87-99.

Picón, A., J.M. Martínez-Jávega, J. Cuquerella, M.A. Del Río, and P. Navarro. 1993. Effects of precooling, packaging film, modified atmosphere and ethylene absorber on the quality of refrigerated Chandler and Douglas strawberries. Food Chem. 48:189-193.

Prussia, S.E. and R.L. Shewfelt. 1993. Systems approach to postharvest handling, p. 44-71. In: R.L. Shewfelt and S.E. Prussia (eds.). Postharvest handling: A systems approach. Academic Press, San Diego, CA.

Qadir, A., E.W. Hewett, and P.G. Long. 1997. Ethylene production by Botrytis cinerea. Postharvest Biol. Technol. 11:85-91.

Saltveit, M.E. 1997. Physical and physiological changes in minimally processed fruits and vegetables, p. 205-220. In: F.A. Tomaìs-Barberaìn and R.J. Robbins (eds.). Phytochemistry of fruit and vegetables. Oxford University Press, Oxford, UK.

Schoorl, D. and J.E. Holt. 1980. Bruise resistance measurements in apples. J. Texture Stud. 11:389-394.

Szczesniak, A.S. and B.J. Smith. 1969. Observation on strawberry texture: A three-pronged approach. J. Texture Stud. 1:65-89.

Tian, M.S., S. Prakash, H.J. Elgar, H. Young, D.M. Burmeister, and G.S. Ross. 2000. Responses of strawberry fruit to 1-methylcyclopropene (1-MCP) and ethylene. Plant Growth Regulat. 32:83-90.

U.S. Department of Agriculture (USDA). 2006. United States Standards for grades of straw- berries. 10 Nov. 2019. <https://www.ams. usda.gov/sites/default/files/media/Strawberry_ Standard\%5B1\%5D.pdf $>$.

U.S. Department of Agriculture (USDA). 2019. Food availability (Per capita) data system: Fruit (fresh). 10 Nov. 2019. <https://www.ers.usda.gov/ data-products/food-availability-per-capita-datasystem/>.

Van Linden, V., N. Scheerlinck, M. Desmet, and J. De Baerdemaeker. 2006. Factors that affect tomato bruise development as a result of mechanical impact. Postharvest Biol. Technol. 42:260-270.

Wills, R.B.H. and G.H. Kim. 1995. Effect of ethylene on postharvest life of strawberries. Postharvest Biol. Technol. 6:249-255.

Wills, R.B.H. and T. Wong. 1996. Effect of low ethylene levels on the storage life of the Asian leafy vegetables Bak Choi (Brassica chinensis), Choi Sum (Brassica parachinensis) and Gai Lan (Brassica alboglabra). ASEAN Food J. 11:145-147.

Wills, R.B.H., V.V.V. Ku, D. Shohet, and G.H. Kim. 1999. Importance of low ethylene levels to delay senescence of non-climacteric fruit and vegetables. Austral. J. Exp. Agr. 39:221224. 